\title{
The Lithium Bromide Dew Cell
}

\author{
Donald T. Acheson \\ U.S. Weather Bureau, Washington, D. C. \\ 4 May 1965 and 14 July 1965
}

\section{Introduction}

The dew cell is a hygrometer which functions by automatically regulating the temperature of a saturated aqueous salt solution so that the water vapor pressure of the solution is equal to that of the surrounding atmosphere. The details of its construction and operating are described elsewhere by Hickes (1947), Tanner and Suomi (1956) and Acheson (1963). The functional range of the dew cell is determined by the vapor pressure vs. temperature curve of the saturated salt solution employed. Dew-point temperature measurements can be made over the range of relative humidities from about 11 per cent to 100 per cent using lithium chloride
$(\mathrm{LiCl})$. This range can be extended from about 5 per cent to 100 per cent by using lithium bromide ( $\mathrm{LiBr})$. The minimum relative humidity is shown in detail in Fig. 1 as a function of ambient temperature for both $\mathrm{LiCl}$ and $\mathrm{LiBr}$. Tables 1 and 2 give the water vapor pressure and equivalent dew point vs. temperature of the saturated solution (actual dew-cell temperature) for LiBr. Fig. 2 graphically portrays the dew-point vs. dew-cell temperature data given in Table 1. Data for both the figures and tables have been derived from measurements of the vapor pressures of saturated solutions vs. temperature performed by Acheson (1965). The vapor pressure of $\mathrm{LiBr}$ is not given in this reference, 


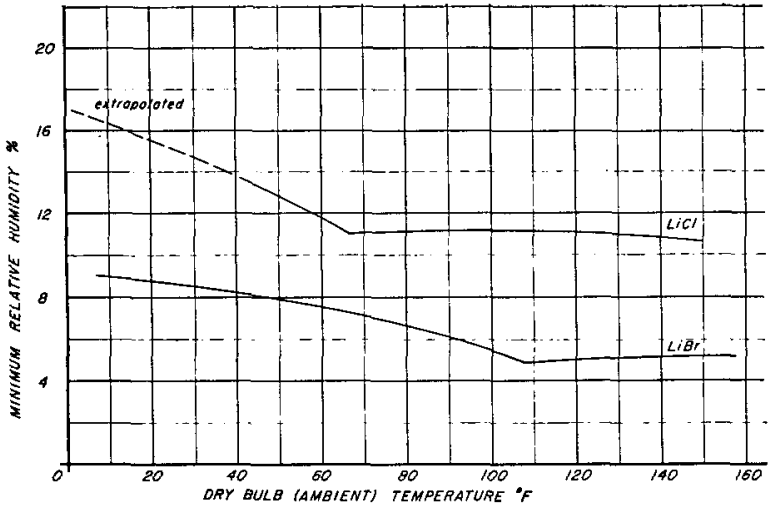

FiG. 1. Low relative humidity bound for $\mathrm{LiBr}$ and $\mathrm{LiCl}$ dew cells.

Table 1. Water vapor pressure and equivalent dewpoint vs. temperature of a saturated $\mathrm{LiBr}$ solution.

\begin{tabular}{cccccc}
\hline $\begin{array}{c}\text { Vapor } \\
\text { pres- } \\
\text { sure } \\
\text { (milli- } \\
\text { bars) }\end{array}$ & $\begin{array}{c}\text { Equiva- } \\
\text { lent } \\
\text { dew- } \\
\text { point } \\
\left({ }^{\circ} \mathrm{F}\right)\end{array}$ & $\begin{array}{c}\text { Solution } \\
\text { tempera- } \\
\text { ture } \\
\left({ }^{\circ} \mathrm{F}\right)\end{array}$ & $\begin{array}{c}\text { Vapor } \\
\text { pressure } \\
\text { (millibars) }\end{array}$ & $\begin{array}{c}\text { Equiva- } \\
\text { lent } \\
\text { dew- } \\
\text { point } \\
\left({ }^{\circ} \mathrm{F}\right)\end{array}$ & $\begin{array}{c}\text { Solution } \\
\text { tempera- } \\
\text { ture } \\
\left({ }^{\circ} \mathrm{F}\right)\end{array}$ \\
\hline 0.19 & -40 & 6.5 & 5.63 & 30 & 118.8 \\
0.25 & -35 & 13.2 & 6.89 & 35 & 125.8 \\
0.33 & -30 & 20.1 & 8.39 & 40 & 132.6 \\
0.43 & -25 & 27.1 & 10.17 & 45 & 139.8 \\
0.56 & -20 & 34.2 & 12.27 & 50 & 146.8 \\
0.73 & -15 & 41.5 & 14.75 & 55 & 154.0 \\
0.93 & -10 & 48.9 & 17.66 & 60 & 161.2 \\
1.20 & -5 & 56.7 & 21.07 & 65 & 168.4 \\
1.52 & 0 & 64.6 & 25.03 & 70 & 176.0 \\
1.91 & 5 & 72.9 & 29.63 & 75 & 183.4 \\
2.40 & 10 & 81.5 & 34.96 & 80 & 190.8 \\
2.99 & 15 & 91.0 & 41.10 & 85 & 198.3 \\
3.71 & 20 & 103.5 & 48.15 & 90 & 206.6 \\
4.04 & 22 & 108.0 & 56.24 & 95 & 214.2 \\
4.58 & 25 & 111.9 & 65.47 & 100 & 222.3 \\
\hline & & & & &
\end{tabular}

TABLE 2. Water vapor pressure and equivalent dew point vs. temperature of a saturated $\mathrm{LiBr}$ solution.

\begin{tabular}{cccccc}
\hline $\begin{array}{c}\text { Vapor } \\
\text { pressure } \\
\text { (milli- } \\
\text { bars) }\end{array}$ & $\begin{array}{c}\text { Equiva- } \\
\text { lent } \\
\text { dew } \\
\text { point } \\
\left({ }^{\circ} \mathrm{C}\right)\end{array}$ & $\begin{array}{c}\text { Solution } \\
\text { tempera- } \\
\text { ture }\left({ }^{\circ} \mathrm{C}\right)\end{array}$ & $\begin{array}{c}\text { Vapor } \\
\text { pressure } \\
\text { (millibars) }\end{array}$ & $\begin{array}{c}\text { Equiva- } \\
\text { lent } \\
\text { dew } \\
\text { point } \\
\left({ }^{\circ} \mathrm{C}\right)\end{array}$ & $\begin{array}{c}\text { Solution } \\
\text { tempera- } \\
\text { ture }\left({ }^{\circ} \mathrm{C}\right)\end{array}$ \\
\hline 0.19 & -40 & -14.2 & 8.72 & 5 & 56.7 \\
0.31 & -35 & -7.6 & 12.27 & 10 & 63.9 \\
0.51 & -30 & -0.3 & 17.04 & 15 & 71.0 \\
0.81 & -25 & 6.8 & 23.37 & 20 & 78.3 \\
1.25 & -20 & 14.6 & 31.67 & 25 & 85.7 \\
1.91 & -15 & 22.7 & 42.43 & 30 & 93.4 \\
2.86 & -10 & 31.7 & 56.24 & 35 & 101.3 \\
4.21 & -5 & 42.9 & 73.78 & 40 & 109.4 \\
6.11 & 0 & 49.8 & & & \\
\hline
\end{tabular}

but was obtained with the same apparatus and identical techniques described there.

The information offered here is the result of preliminary testing designed to demonstrate that a simple substitution of $\mathrm{LiBr}$ for $\mathrm{LiCl}$, without other significant equipment modification, is all that is necessary to extend the functional range of the dew cell. Further

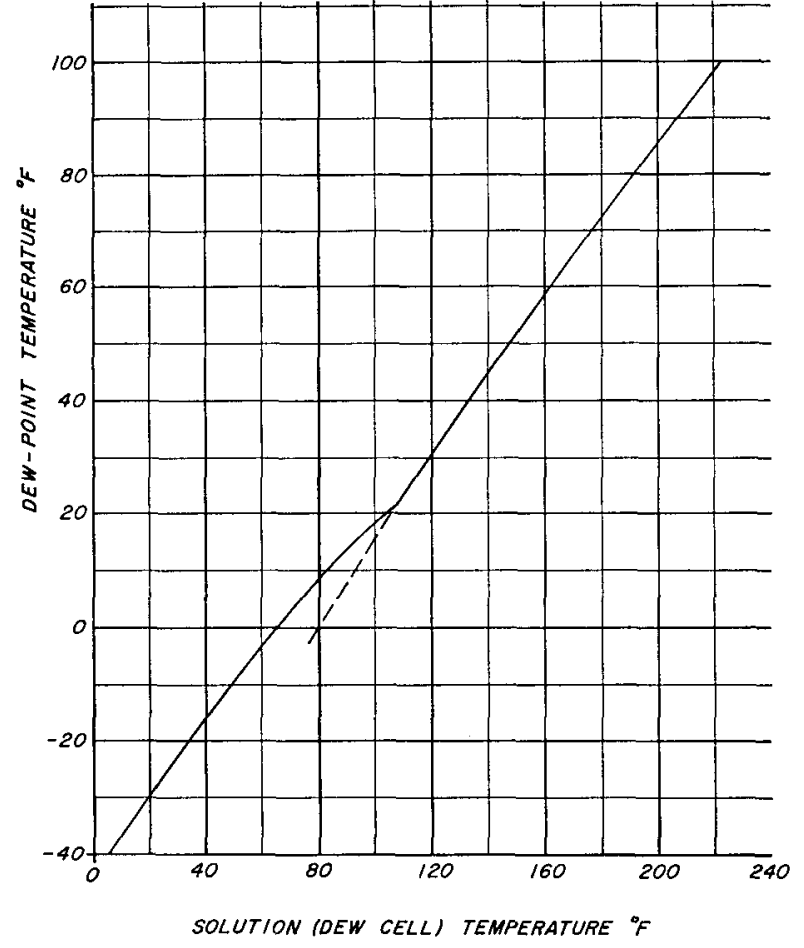

FIG. 2. LiBr dew-point vs, dew-cell temperature.

environmental testing is planned to ensure acceptable operation in environmental extremes and to obtain a statistically significant number of observations in comparison with another hygrometer to validate the accuracy estimates made after this preliminary phase of the investigation.

\section{Discussion}

$\mathrm{LiBr}$ was substituted for $\mathrm{LiCl}$ in a Foxboro model 2711AAG dew cell and, on the basis of the data given in Table 1 and the resistance vs. temperature curve for the thermometer in the dew cell, a range card and scale prepared for a Bristol model WG-ORB66033-06-S19 indicator. The indicator servomechanism and dew-cell resistance thermometer are nearly linear with resistance, but the scale is not linear with dew point. The nonlinearity can be seen in Fig. 2. The discontinuity at a dew-point temperature of $22 \mathrm{~F}(-5.5 \mathrm{C})$ in Fig. 2 arises as a result of a transition in the crystalline phase of $\mathrm{LiBr}$ at a temperature of $41.96 \mathrm{C}$ (107.5F). At this temperature a molecule of water of hydration is lost to the hydrated crystal with increasing temperature and gained with decreasing temperature.

The LiBr dew cell was installed in an HO60 hygrothermometer shield ${ }^{1}$ (a Weather Bureau enclosure providing aspiration and protection from precipitation

"Aspirator Assembly, Thermal Shield" USWB Spec. 450.1450/1, Revised March 1, 1963; "Thermal Shield, Aspirated Temperature System Type" USWB Drawings $450.1315 / \mathrm{A}$ and 450.1315/B dated March 18, 1958. 
and solar radiation for a thermometer and hygrometer) in Washington, D. C., during July 1964 and operated continuously during the remaining summer months and throughout the autumn and winter. The dew points encountered during this period ranged from $-5 \mathrm{~F}$ to $+80 \mathrm{~F}$ ( $-21 \mathrm{C}$ to $+27 \mathrm{C})$. Comparison with several $\mathrm{LiCl}$ dew cells, an infrared (IR) hygrometer (Staats et al., 1965), and a Peltier-cooled dew-point hygrometer (Francisco and Beaubien, 1965) demonstrated to the author's satisfaction that the $\mathrm{LiBr}$ dew cell will yield measurements accurate to within $\pm 1 \mathrm{~F}$ over the range encountered.

To obtain further information, a second $\mathrm{LiBr}$ dew cell was installed at Yucca Flat, Nevada, during August 1964 and operated for about one month. This installation differed from that in Washington in one significant feature. An unaspirated weather shield, a Foxboro model 2714 Weatherhood, was used in Nevada. The primary comparison instrument there was a wet-anddry bulb psychrometer, with an IR hygrometer occasionally available. The latter instrument afforded no meaningful data, since it was operating incorrectly at least part of the time, unknown to the observer. For this reason, the author chose to disregard all of the data furnished by this instrument. After discarding the $\mathrm{LiBr}$ dew-cell readings when the psychrometer showed an ambient relative humidity of less than 6 per cent, 328 observations were available for comparison. The mean difference between the $\mathrm{LiBr}$ dew cell and the psychrometer was calculated as plus $0.3 \mathrm{~F}$, but the standard deviation is estimated at 4 or $5 \mathrm{~F}$. This large scatter may be attributed to the difficulties of employing the psychrometer at low dew points and large wet bulb depressions or to the $\mathrm{LiBr}$ dew cell. As a result of the data obtained from Nevada, the author is disinclined to place very much faith in the unaspirated dew cell.

As noted by Conover (1950), the $\mathrm{LiCl}$ dew cell experiences an abrupt "pulse" in its indicated dew point in passing through a dew-point temperature of $11 \mathrm{~F}$ after operating at lower dew points for prolonged periods. This is accounted for by the abrupt release of water from the hydrated crystals of $\mathrm{LiCl}$ on the wick to the solution on the wick. Tanner and Suomi (1958) did not note this phenomenon although ample opportunity for its occurrence existed in their tests. This LiBr dew cell should experience a similar "pulse" at a dew point of about $22 \mathrm{~F}(-5.5 \mathrm{C})$. This has been noted twice. The change in the reading under such circumstances is fast when the aspirated enclosure is used and no confusion exists.
Another aspect of the phase transition of $\mathrm{LiBr}$ of $22 \mathrm{~F}(-5.5 \mathrm{C})$ dew point is that below this temperature two crystalline phases can exist; one thermodynamically stable and the other thermodynamically unstable, somewhat analagous to the existence of either ice or supercooled water below $32 \mathrm{~F}(0 \mathrm{C})$. The two phases differ in that the unstable form is a continuation, shown as a dashed line in Fig. 2, of the stable form above $22 \mathrm{~F}(-5.5 \mathrm{C})$. The author is not aware of any experimental data to support the coordinates on the extrapolation, so no quantitative value should be attached to it. At dew points below $+10 \mathrm{~F}\left(-12^{\circ} \mathrm{C}\right)$, the difference between the two curves should be easily discernable in any comparison between the $\mathrm{LiBr}$ dew cell and another hygrometer not subject to this ambiguity, such as the IR hygrometer. This comparison demonstrated that the $\mathrm{LiBr}$ dew cell provides a reading consistent with the stable phase to within $\pm 1 \mathrm{~F}$.

\section{Conclusions}

The substitution of $\mathrm{LiBr}$ for $\mathrm{LiCl}$ in the dew cell extends the range of measurable dew points to include those occurring at ambient relative humidities approaching 5 per cent instead of 11 per cent.

The preliminary assessment of accuracy, based on the experience obtained with an aspirated $\mathrm{LiBr}$ dew cell operated in Washington, D. C., for about 8 months in comparison with an infrared hygrometer and a Peltier-cooled hygrometer, is $\pm 1 \mathrm{~F}$.

\section{REFERENCES}

Acheson, D. T., 1963: Some limitations and errors inherent in the use of the dew cell for measurement of atmospheric dewpoints. Mon.Wea. Rev., 91, 183-190.

_-, 1965: Vapor pressures of saturated aqueous salt solutions. Humidity and Moisture: Measurement and Control in Science and Industry. Vol. 3, New York, Rheinhold, 521-530.

Conover, J. H., 1950: Tests and adaptation of the Foxboro dewpoint recorder for weather observatory use. Bull. Amer. Meteor. Soc., 31, 13-22.

Francisco, C. C., and D. J. Beaubien, 1965: An automatic dewpoint hygrometer with thermoelectric cooling. Humidity and Moisture: Measurement and Control in Science and Industry. Vol. 1, New York, Rheinhold, 165-173.

Hickes, W. F., 1947 : Humidity measurement by a new system. Refrig. Eng., 54, 351-354 and 388.

Staats, W. F., et al., 1965: Infrared absorbtion hygrometer. Humidity and Moisture: Measurement and Control in Science and Industry. Vol. 1, New York, Rheinhold, 465-480.

Tanner, C. B., and V. E. Suomi, 1956: Lithium chloride Dewcel properties and use for dew-point and vapor-pressure gradient measurements. Trans. Amer. Geophys. Union, 37, 413-420.

— and - 1958: A max-min dew-point hygrometer. Trans. Amer. Geophys. Union, 39, 63-66. 